\title{
A Model Proposal For Logistics Center Capacity Evaluation: Kars Logistics Center Example
}

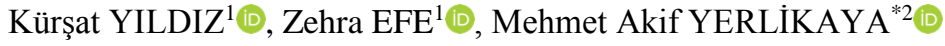 \\ ${ }^{1}$ Gazi University, Faculty of Technology, Department of Civil Engineering, Ankara, Turkey \\ ${ }^{2}$ Bitlis Eren University, Faculty of Engineering and Architecture, Department of Industrial Engineering, \\ Bitlis, Turkey \\ *mayerlikaya@beu.edu.tr
}

(Alınış/Received: 16.05.2021, Kabul/Accepted: 16.06.2021, Yayımlama/Published: 31.07.2021)

\begin{abstract}
Turkey is one of the few countries that ambitiously tries to build new logistics centers. KarsTurkey has a strategic importance in terms of logistics and transportation center due to its geographical features. In Kars province, the construction of the logistics center was launched in 2017. On the other hand, "Capacity" is a very important parameter for logistics centers, especially ones that manage large commercial flows. Insufficiency or excess capacity may cause negative issues, in terms of cost and space. In this study, the freight capacity assessment of Kars logistics center has been made and a logistics model that maximizes the capacity utilization has been proposed according to this assessment. This logistics model consists of three stages: The first is the estimation of the future freight transport amounts with the Exponential Smoothing method according to the past freight transport data. The second is to determine the alternative transportation scenarios that maximize the capacity utilization of the Kars logistics center with a mathematical model. Third, the TOPSIS method is the most suitable one among these alternative scenarios. Because the best use of capacity in logistics centers has become a problem, the proposed model is intended to be a reference for all logistics centers. Thus, we aim to provide efficient usage of the Kars logistics center by its full capacity. The solution results have been revealed that the proposed model is effective and valid. In the literature, there is no model that maximizes capacity utilization and determines the optimal transport scenario for a logistics center.
\end{abstract}

Keywords: Logistics center capacity, Exponential Smoothing, Mathematical model, TOPSIS

\section{Lojistik Merkez Kapasite Değerlendirme İçin Bir Model Önerisi: Kars Lojistik Merkez Örneği}

Öz: Türkiye, yeni lojistik merkezlerin inşa edilmesi konusunda iddialı olan az sayıdaki ülkelerden biridir. Kars ili, coğrafik özellikleri nedeniyle lojistik ve ulaşım merkezi açısından stratejik bir öneme sahiptir. Kars ilinde lojistik merkezin inşaatına 2017 yılında başlanmıştır. Öte yandan, özellikle büyük ticari akışları yöneten lojistik merkezler için "Kapasite" çok önemli bir parametredir. Yetersiz veya fazla kapasite, maliyet ve yer açısından olumsuz sorunlara neden olabilir. Bu çalışmada, Kars lojistik merkezinin yük kapasitesi değerlendirmesi yapılmış ve bu değerlendirmeye göre kapasite kullanımını maksimize eden bir lojistik model önerilmiştir. Bu lojistik model üç aşamadan oluşmaktadır: Birincisi, geçmiş yük taşıma verilerine göre Üstel Düzeltme yöntemi ile gelecekteki yük taşıma miktarlarının tahmin edilmesidir. İkincisi, Kars lojistik merkezinin kapasite kullanımını maksimize eden alternatif ulaşım senaryolarının matematiksel bir model ile tespit edilmesidir. Üçüncüsü, Çok Ölçütlü Karar Verme yöntemlerinden olan TOPSIS yöntemi bu alternatif senaryolar arasından en uygun olanının seçilmesidir. Lojistik merkezlerde kapasitenin en iyi şekilde kullanılması sorun haline geldiğinden, önerilen modelin tüm lojistik merkezler için iyi bir referans olması amaçlanmıştır. Böylece, Kars lojistik merkezinin tam kapasite ile verimli kullanılmasını hedefliyoruz. Çözüm sonuçları önerilen modelin etkili ve geçerli olduğunu ortaya koymuştur. Literatürde bir lojistik merkez için kapasite kullanımını maksimize eden ve optimal taşıma senaryosunu belirleyen bir model bulunmamaktadır.

Anahtar kelimeler: Lojistik merkez kapasitesi, Üstel düzeltme, Matematiksel model, TOPSIS 


\section{Introduction}

Globalization and liberalization have been presented as the main reasons for the growth of global trade volume. The growth of trade volume has brought different dimensions for international trade, however, every country wanted to take maximum benefit from this game - for someone, this was a zero-sum game.

In this process, competition has become a prominent factor. Then countries have realized the importance of the logistics sector to go one step further in the competitive environment and they have started to generously invest in the logistics sector. Although European countries are at a more advanced level in logistics, America was the first one that realizes the importance of logistics. Also, in Turkey, Logistics has been assumed as a strategic sector in the last 50 years [1].

Logistical activities, which are constantly developing in Turkey, have been considered important and some studies have been made by the government about it. On the other hand, the development of technological facilities and strengthening of capital's free movement provided good relations with the Western countries to Turkey. This can be shown as one of the important reasons for the development of the logistics industry of Turkey [2]. Since being a strategic country, Turkey intended to be the logistical hub in the regions of Balkans, the Middle East, Caucasus, and the Black Sea.

"Logistics Center" is defined "as the area where the operations related to transportation, transportation, and distribution of freight are carried out by different companies". Turkey is a potential logistics center and so far, 25 logistics centers have been requested. It was stated that 9 of them were put into operation, 2 of them were completed, 2 of them were in the construction process and the others were in contract, tender, and project stages. However, there are many important parameters, which affect the efficiency of logistics centers. It can be sorted as transportation, infrastructure, location, facilities, and land features [3]. It was emphasized that the freight capacity is of great importance as well as the importance of the transportation network for logistics centers. A precise definition of the freight capacity has not been made yet. However, it is generally defined as "the maximum amount of freight which is transported in a certain time period". On the other hand, the freight capacity is not a static concept; it is a concept that depends on many variables. These variables may contain many parameters such as train type, line type, and line length [4].

Kars province -as a gateway to Central Asia and the Caucasus-provides a reliable bridge for trade between China and the EU. The strategic potential of Kars has been strengthened by Ankara-Kars high-speed train, Kars-Tbilisi-Baku railway line, and the Kars-Igdir-Nakhchivan(Azerbaijan)Iran railway projects, which are under construction currently (Serhat Development Agency). That is why Kars should be seen as a very strategic bridge for EU-China trade relations.

This study aims at determining the freight capacity of the logistics center of Kars, in the context of international economic relations and the ongoing construction of the logistics center in Kars. In the analysis phase, we aim to estimate the amount of freight in the coming years with the "exponential smoothing". By using these estimated data, the maximum capacity of the logistics center and annual train transport statistics can be calculated. Finally, the TOPSIS method has been used to select the most appropriate scenario among alternative scenarios. In the studies in the literature, a situation assessment related to capacity analysis has been made widely. However, there is no study that has a mathematical model that determines the best transportation scenario for a logistics center. Thus, we aim to provide efficient usage of the Kars logistics center by its full capacity. 


\section{Literature Review}

Supply Chain Management Professionals defined Logistics as "planning, implementing and auditing the necessary procedures for the effective and efficient transportation and storage of all products and related information, including services in line with the needs of the customer, from departure to arrival." According to the international EUROPLATFORM organization, the logistics center is "a transportation enterprise where all activities - related to transportation, logistics, and distribution- are carried out in national and international coherency and these activities are provided by different operators" [5].

There are many studies in the literature regarding the efficient use and operation of logistics centers. In most of these studies, optimization/simulation models at an urban scale focusing on freight transport, capacity, and location selection were taken into account. Yildiz et al. [5] stated that the amount of freight and capacity carried as important as the transportation network for logistics centers. Li et al. [6] presented conceptual and mathematical models in which passengers and areas are handled in an integrated manner by the same transport network. Fatnassi et al. [7] studied intermodal road-rail transport and explored the potential of an integrated and rapid transit system in urban areas. Kikuta et al. [8] present a study explaining the potential environmental and operational benefits of using a public metro for urban logistics. Motraghi and Marinov [9] developed a different simulation model to analyze the current situation and evaluate alternatives for freight transport using the urban rail infrastructure in Newcastle. Figliozzi [10], who is inspired by the perspective of the vehicle route, developed a simulation model to measure the economic impact of urban commercial tours. Benjelloun and Crainic [11] presented an overview of city logistics concepts, models, and planning issues, and identified new research paths based on the analysis of many projects. Behrends [12], who worked on the intermodal road-rail transport problem, identified possible actions at the local level that improves both the competitiveness and environmental benefits of urban freight transport. After all, we should know that there is no clear definition of capacity in freight transport. It is a multilateral concept that can be affected by many factors. On the other hand, Robert and Erhan [13] define the capacity as "the maximum number of trains or traffic amount that can cross the entire railway or certain critical sections in a given period time." It was emphasized that the logistics center capacity depends on some uncertain parameters. Sun et al. [14], say that whereas some external factors such as bad weather conditions and technical problems may negatively affect the "capacity"; other factors such as equipmentpersonnel competence and technological shrewdness may positively affect the "capacity". Xue, Huang, Wu, Yan, and Zheng [15] assume the number of businesses or the size of businesses as a measuring tool of capacity. Peceny et al. [16] discussed the optimization of transportation processes within a logistics center chain. They aimed to prepare a measure proposal within the transportation processes and then evaluate them economically, the information obtained through the analysis of the current situation of a part of the logistics chain of a selected enterprise. Abramovic et al. [17] used graphical, analytical, and simulation methods to analyze railway capacity in freight transport. Bevrani et al. [18] focused on multimodal transport systems (MMTS) and their capacity assessment. For this, they developed a linear programming model (LP) represented by MMTS-CAP. Bešinović and Goverde [19] emphasized that capacity assessment and identification of bottlenecks are essential to guarantee the operations of railway networks. They proposed a capacity assessment model based on a new algebraic approach based on correct start and inhibition time calculations. Claessen et al. [20] stated that the rail capacity calculation is extensive and complex. They emphasized that construction projects are superficial and temporary. They stated that this requires a comprehensive capacity calculation. They proposed a programming language that expresses features such as run time, train frequency, overtaking, and transition for appropriate capacity characteristics in construction projects.

In the studies in the literature, a situation assessment related to capacity analysis has been made widely. In this study, a logistics model has been proposed for the Kars logistics center. This 
logistics model consists of three stages: The first is the estimation of the future freight transport amounts with the Exponential Smoothing method according to the past freight transport data. The second is to determine the alternative transportation scenarios that maximize the capacity utilization of the Kars logistics center with a mathematical model. Third, the TOPSIS method is the most suitable one among these alternative scenarios. In the literature, there is no model that maximizes capacity utilization and determines the optimal transport scenario for a logistics center. The proposed model has been applied for Kars logistics center and has been aimed to be a reference for other logistics centers.

\section{As An Example Area of Kars Province and Its Data Set}

Kars is a city, which is located in eastern Turkey and on the route of the historical Silk Road. Kars province, which has an area of $10,193 \mathrm{~km}^{2}$, is located in the northeast of the Eastern Anatolia region (Figure 1). Its population consists of 285, 410 people (TURKSTAT). There are 8 districts in totally. The economy of the province is mainly based on agriculture and animal husbandry.

The criteria of a logistics center can be split into 5 different titles. These are; area suitability (A1), background facilities (A2), transportation (A3), property conditions (A4), location, and interconnected business activities (A5). When five titles are listed in order of importance in the studies, the result is A3> A5> A4> A2> A1 [21]. It has been stated that the logistics center in Kars has the most important criteria (road, railway, airway transportation facilities) and may be referred to as the "Center of the East" shortly with its east-west and north-south connections.

The adjacency of the Kars logistics center to transportation modes provides this result to the city. At the location of the Kars logistics center, there is an integrated railway, road and airport. Furthermore, the Baku-Tbilisi-Kars railway line is passing through Kars. Together with the BTK - (Baku-Tbilisi-Kars) line, the Kars logistics center will create a corridor, which reaches Europe from Chinese and Turkic-countries, and thus it provides significant advantages to commercial companies that imports or exports goods between Europe and Asia. Besides, the Kars logistics center is located close to Kars Planned Organized Industrial Zone. Kars Logistics center's construction process was launched in April 2017, in the area of 300,000 m2 and 70\% of it has been completed since 2017. The sections and sizes of the logistics center are given in Table 1.

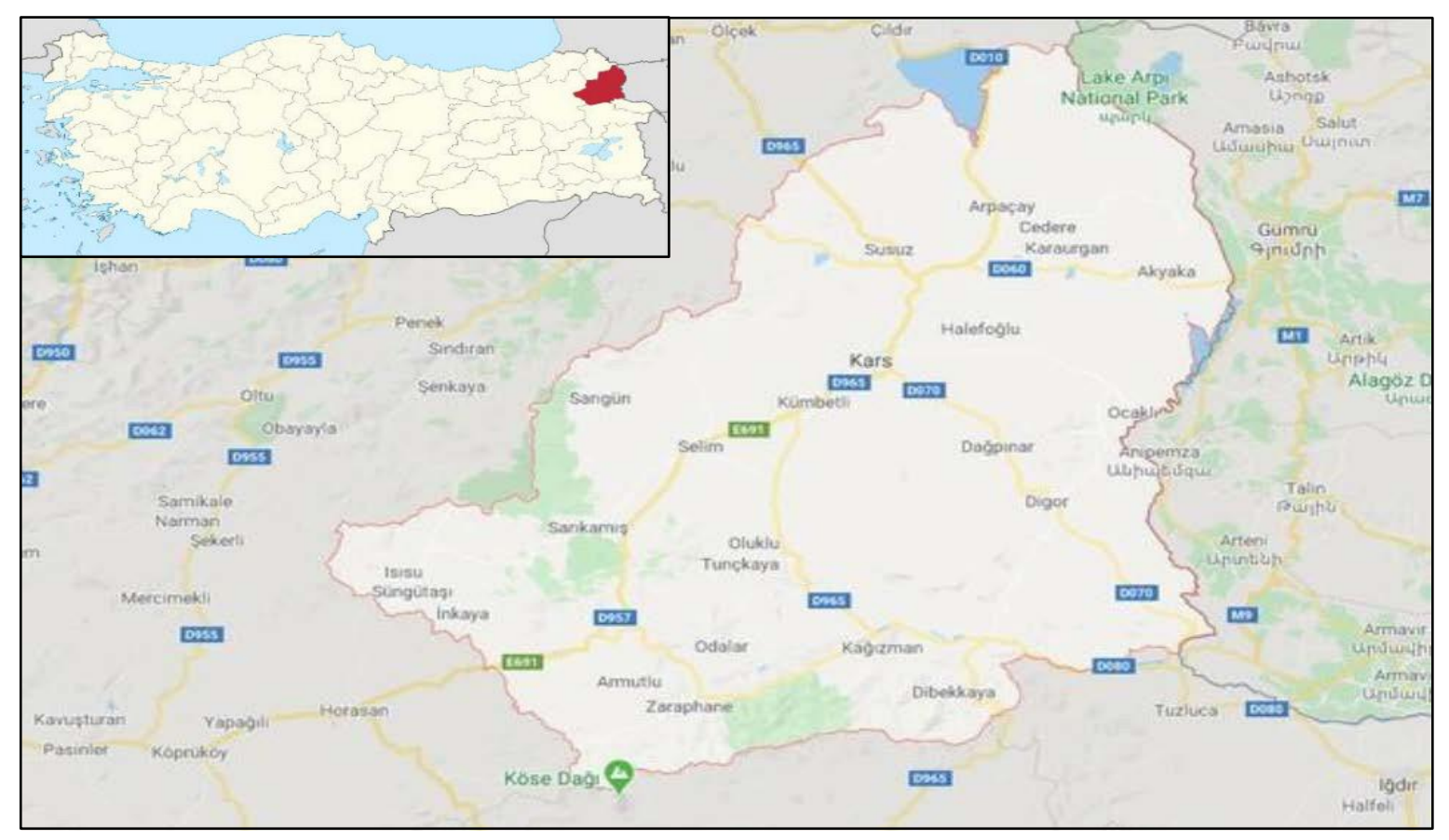

Figure 1. Map of Kars Province 
Table 1. Information of the buildings in the Kars logistics center

\begin{tabular}{|c|c|}
\hline Logistics center Usage Area & Size $\left(\mathrm{M}^{2}\right)$ \\
\hline Entrance Control Building & 40 \\
\hline Workshop for Locomotive and Wagon Maintenance & 8800 \\
\hline Building of The Traffic Facilities and Logistics Directorate & 1500 \\
\hline Building of Administrative and Social Affairs & 2700 \\
\hline Building for Social Activities & 1300 \\
\hline Traffic Watchtower and Technical Building for Signalization \& Electrification & 750 \\
\hline Electricity Transformer Center & 160 \\
\hline Stock Room for Water & 260 \\
\hline Building for weightbridge & 40 \\
\hline Housing for Workers & 260 \\
\hline Garage for Road Devices & 3100 \\
\hline Warehouse for Smaller Stuffs and Items & 130 \\
\hline Warehouse of Bigger Materials for Traverse and Bridge & 130 \\
\hline Road Materials for Maintenance and Repairing & 130 \\
\hline Directorate for Maintenance & 430 \\
\hline Garage for Pickups and Trucks & 380 \\
\hline Entrepot & 10000 \\
\hline
\end{tabular}

\subsection{Data set}

The first steps of the Baku-Tbilisi-Kars (BTK) railway, which is known as the Iron Silk Road, were taken in 2007 in Georgia and 2008 in Kars(Turkey). The first train started operating on October 30, 2017. The First Line started operations with a million passengers and 6.5 million tons of freight capacity. In 2034, it is aimed to increase the number of passengers to 3 million and the freight capacity to 17 million tons [22].

The railway route consists of double and single lines. It has been arranged as a double line (108 $\mathrm{km})$ from Kars to Ahilkelek, a single line $(155 \mathrm{~km})$ from Ahılkelek to Tbilisi, and a double line $(566 \mathrm{~km})$ from Tbilisi to Baku. The line was designed to pass through both Kazakhstan and Turkmenistan after Baku (Azerbaijan) and then divided into two ways whereby it can go to Central Asia and then to China. Figure 2 shows the route of the BTK (Baku-Tbilisi-Kars) railway. 


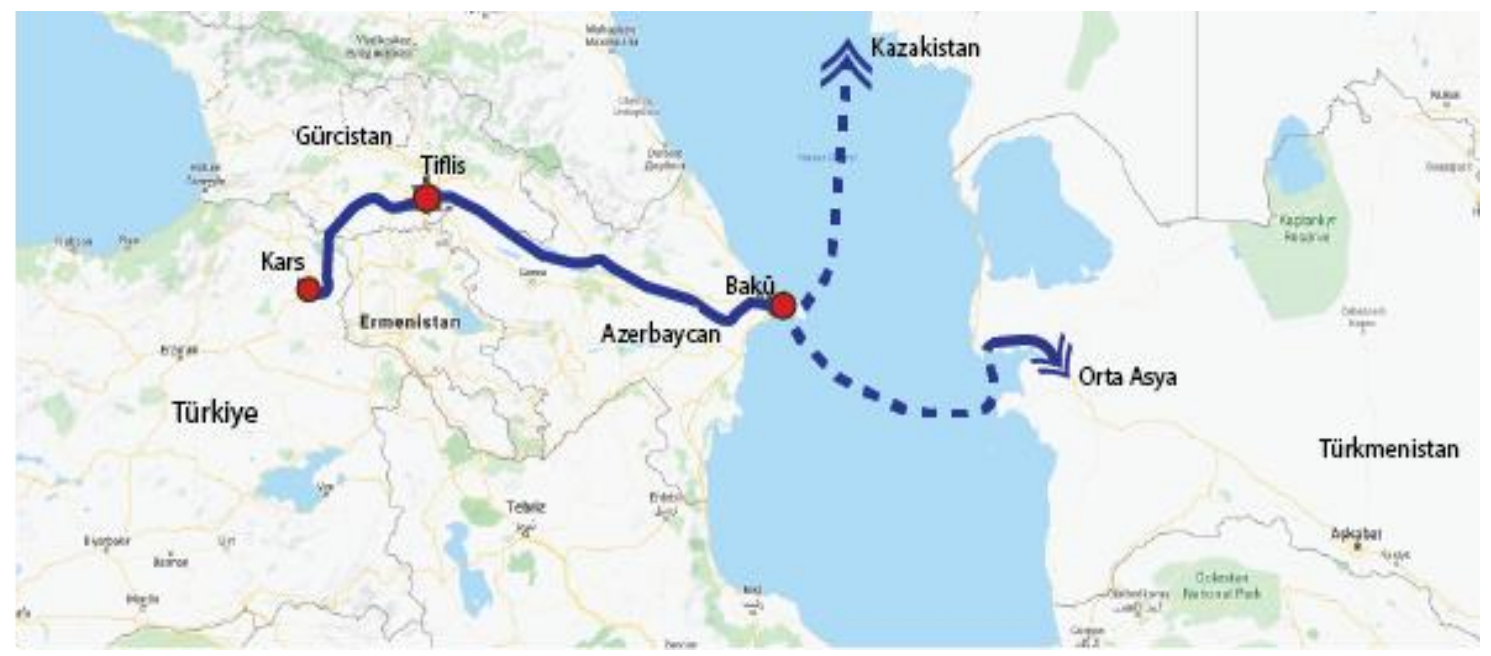

Figure 2. BTK railway route

The freight - which comes from Georgia to Kars-goes to three different routes in Turkey. These are Iskenderun, Mersin, and Derince (Izmit). Mersin, Iskenderun (Hatay), and İzmit are important seaport cities of Turkey. The busiest line is the Kars-İskenderun line. The amount of freight received by BTK to the Kars station in the last 3 years is 122,504 tons (Figure 3), and the amount of freight sent by BTK from the Kars station in the last 3 years is 25,852 tons (Figure 4)

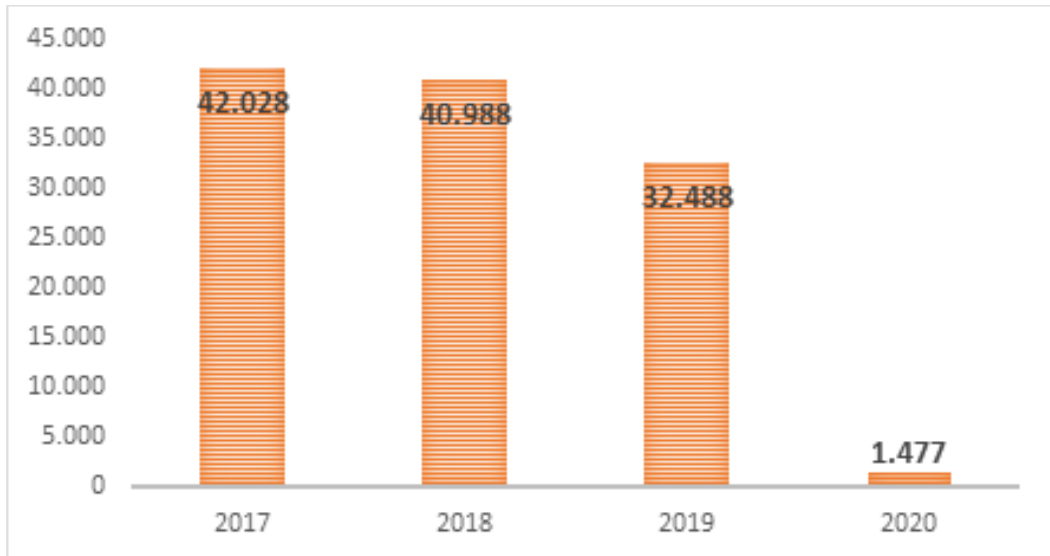

Figure 3. The amount of freight in BTK by years (Ton)

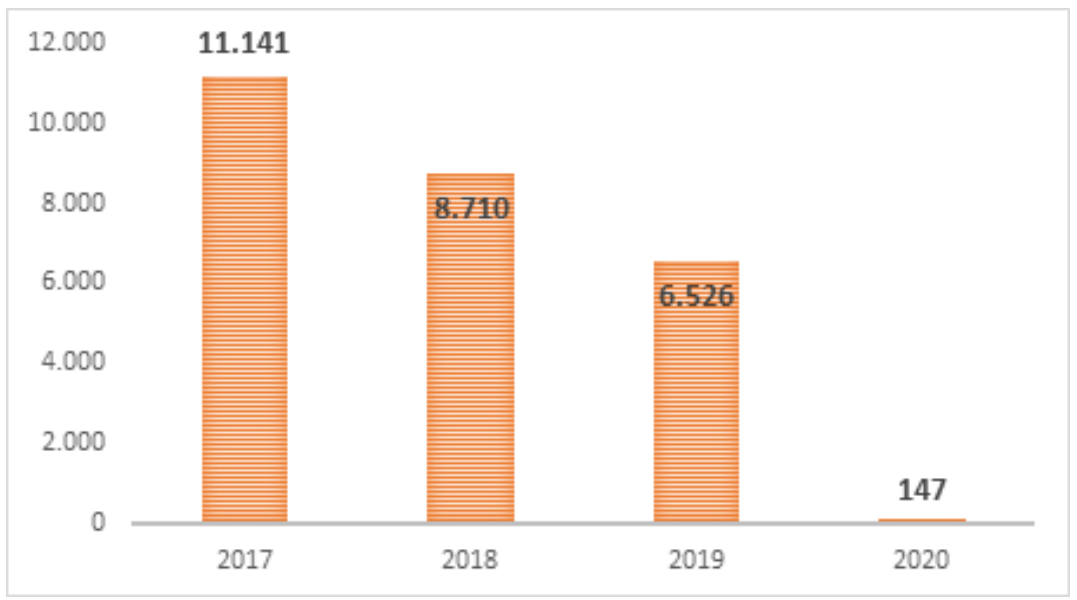

Figure 4. Amount of outgoing freight in BTK by years (Tons) 
The shipments which are carried out in BTK, have been made by nationally produced wagons of TCDD-state-owned railway company- and these wagons have 90 feet wagons, and it is stated that $2 * 40$ or $2 * 45$ feet containers can be freighted (TCDD annual report, 2018). The Kars logistics center has a receiving capacity of approximately 6.4 tons for $2 * 40$ containers and 7 tons for $2 * 45$ containers at the same time. It is possible to transport 1,500 tons of transportation between Ahılkelek and Kars at once, and 1,510 tons between Kars and Ahilkelek. BTK railway currently operates an average of 7 trips per week from Georgia to Kars and uses only 25-30\% of its freight capacity (TCDD). In other words, if the capacity is used fully, we can expect that approximately 3 times more transport will occur than the current transportation. The amount of freight that can be carried from Georgia to Kars in one go is a minimum of 1,500 tons and a maximum of 4,000 tons. However the total capacity of the center is 412,000 tons, and the maximum freight has brought so far is approximately 42,000 tons.

\section{Methodology}

In this study, the freight capacity assessment of a logistics center has been made and a model that maximizes the capacity utilization has been developed according to this assessment. Because the best use of capacity in logistics centers has become a problem, the proposed model is intended to be a reference for all logistics centers. The stages of the proposed model are given in Figure 5. In Figure-5, firstly, the freight ratio for the next years is estimated according to the amount of incoming and outgoing freight at the Kars logistics center in the last 5 years. Here, the ratio is the ratio of the outgoing freight to the incoming freight and is decisive in the capacity analysis. This ratio is between 0 and 1 . At this stage, exponential smoothing is used to avoid relying only on historical data. Secondly, capacity analysis has been made by obtaining alternative load-carrying scenarios that maximize the freight capacity utilization rate using the mathematical model. Thirdly, among these alternative freight transport scenarios, the most suitable one is selected by using the TOPSIS method under certain criteria.

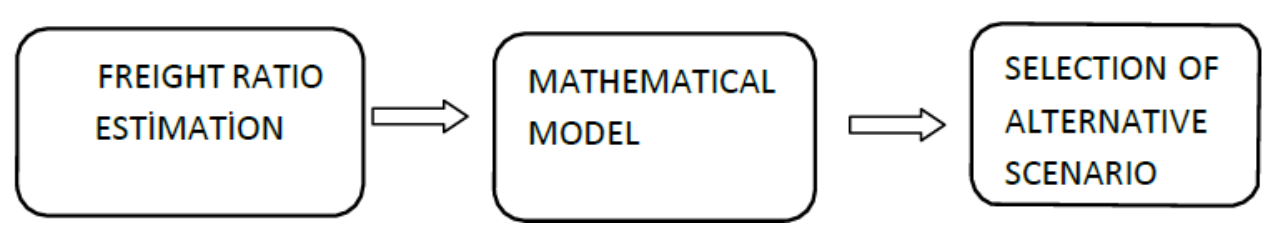

Figure 5. Recommended freight capacity model flow

\subsection{Estimation of the freight ratio with exponential smoothing}

As the first step of the proposed model, the freight ratio of the next years is estimated by using the freight rates for the last 4 years. The outgoing freight rate is calculated over the incoming freight amount. The outgoing freight rate formula is Equation 1:

\section{Outgoing Freight Rate $(p)=$ Outbound Freight Amount / Incoming Freight Amount}

In Equation 1, $\mathrm{p}$ is the outgoing charge ratio and is expressed as a percentage. Using the data for the years 2017-2020, an estimation of the outgoing freight ratio for the following years was made by exponential smoothing. Exponential smoothing is a method whose predictions are constantly updated by considering of latest changes in actual values. The accuracy of the values for weights is of great importance for precise results. The exponential smoothing provides practicality thanks to its simplicity and not requiring much technical knowledge. There are different correction models with different assumptions. However, in the exponential smoothing, the weighted average of the data belonging to the previous period is accepted as the estimations for the future period. The most prominent feature of the method is the fact of every data that is used in the model are 
based on real life. It provides continuity to practitioners of the method. It also provides a dynamic aspect to the method. Based on this, the idea that "recent values should be given more weight compared to previous observations" have been put forward by this method too. Hence, the desired weighting method should use a weighting approach that gives the highest weight to the final observations and decreasing the weight to the previous observations. The exponential smoothing satisfies this necessity completely. In the exponential smoothing, corrected values are obtained as follows Equation 2 [23, 24]:

$$
p_{t}^{l}=a p_{t}+(1-a) p_{t-1}^{l}
$$

In Equation 2, $p_{t}$ expresses the actual value of that period, $p_{t}^{l}$ expresses the estimated value of that period and $\alpha$ expresses the weight of the past values. Here, $\alpha=0.5$ is taken. This is because the number of data considered is limited to only 4 years. Therefore, equal weighting of both historical data and current data yields more efficient forecasting results. The outgoing freight ratio for the years 2017-2020 and the estimated outgoing freight ratio for 2021 are given in Table 2.

As a result of the analysis made with the exponential smoothing, the estimated "p" value for 2021 and the following years will be 0.146 . This value will be an input to the proposed mathematical model.

Table 2. Estimated freight ratios

\begin{tabular}{ccccc}
\hline Year & $\begin{array}{c}\text { Outgoing Freight } \\
\text { Amount }\end{array}$ & $\begin{array}{c}\text { Incoming Freight } \\
\text { Amount }\end{array}$ & $p_{t}$ & $p_{t}^{l}$ \\
\hline 2017 & 11.185 & 46.582 & 0.240115 & - \\
2018 & 9.150 & 46.490 & 0.196813 & 0.240115 \\
2019 & 6.526 & 42.733 & 0.152723 & 0.218 \\
2020 & 147 & 1.477 & 0.1 & 0.192 \\
2021 & - & - & - & 0.146 \\
\hline
\end{tabular}

\subsection{Capacity analysis with mathematical model}

In this section, a mathematical model that maximizes the capacity utilization rate of the Kars logistics center is proposed. The proposed model aims to use the Kars logistics center at maximum capacity and to evaluate the scenarios that arise in this capacity. These scenarios include incoming freight amount, outgoing freight amount, number of train trips, and associated costs. This model is a single purpose and a nonlinear model. Capacity utilization rate, which is the objective function in the model, is given in Equation 3. In this Equation, the storable amount of the amount of freight coming from outside is expressed as a ratio. In Equation 3, $\mathrm{z}$ is the capacity utilization ratio, wt is the annual incoming Freight amount and MC is the maximum capacity. In Equation 4, w is Amount of incoming freight per transport and $t$ is number of trips per year. In Equation 5, the amount of storable freight (maximum capacity) is the sum of the capacity of the logistics center and the amount of outgoing freight. Because, the annual incoming freight amount may be more than the available capacity, as the area is freed for the amount of outgoing freight. In Equation 5, $\mathrm{m}$ is the available capacity and wtp is annual outgoing freight amount. Equation 6 gives the formulation of wtp. 


$$
\begin{array}{r}
z=w t / M C \\
w t=w * t \\
M C=m+w t p \\
w t p=w * t * p
\end{array}
$$

The proposed mathematical model is as follows:

The variables are:

z: Capacity utilization rate,

$\mathrm{w}$ : Amount of incoming freight per transport,

t: Number of trips per year,

wt: Annual incoming freight amount,

wtp: Annual outgoing freight amount.

Parameters are:

m: Current capacity $=412000$ tons

$\mathrm{p}$ : Outgoing freight ratio $=0.146$.

The proposed model is:

Objective function;

$$
\operatorname{Max} z=w t /(m+w t p)
$$

Constraints;

$$
\begin{gathered}
w t /(m+w t p) \leq 1 \\
w \leq 4000 \\
w \geq 1500 \\
t \leq 365 \\
w, t \geq 0
\end{gathered}
$$

In the model, the objective function (Equation 7) expresses the capacity utilization ratio of the incoming freight amount for the Kars logistics center. The goal is to maximize this rate. Constraint (Equation 8), capacity utilization rate cannot be greater than 1, constraint (Equation 9)-constraint (Equation 10), at least 1500 and at most 4000 tons can be transported at one time, constraint (Equation 11), maximum 365 train services per year (if there is a train service every day), and constraint (Equation 12) refer to the positive variable as a constraint. With the help of the proposed mathematical model, taking into account the estimated freight ratio value, the freight amount data that maximizes the capacity use of the logistics center and the annual number of train transportation are obtained. GAMS 35.2.0 (Guide to Available Mathematical Software)/BARON (The Branch-And-Reduce Optimization Navigator) optimization software has been used to implement the model. As a result of the solution, 201 alternative optimal value have been obtained that satisfies $z=1$. The solution test of the model is given in Table 3. Eight of these alternative optimal values have been selected according to the regular weekly train service number. This selection is made according to the regular voyages every week and the minimum and maximum freight quantities that can be transported at once. Eight alternative solutions are presented in Table 4. 
Table 3. The solution test of the proposed model

\begin{tabular}{ccccc}
\hline Solver type & GAMS solver & $\begin{array}{c}\text { Object function } \\
\text { value }\end{array}$ & $\begin{array}{c}\text { Solution time } \\
\text { (second) }\end{array}$ & $\begin{array}{c}\text { Number of } \\
\text { iterations }\end{array}$ \\
\hline $\begin{array}{c}\text { Alternative } \\
\text { optimal solution }\end{array}$ & BARON & 1,0 & 1,65 & 5 \\
\hline
\end{tabular}

Table 4. Alternative solutions according to the number of regular trips

\begin{tabular}{lcc}
\hline & $\begin{array}{c}\text { Freight Per Transport } \\
\text { Trips Per Year }\end{array}$ & Trips Per Year \\
\hline Alternative Solution 1 & 3711 & 130 \\
Alternative Solution 2 & 3092 & 156 \\
Alternative Solution 3 & 2650 & 182 \\
Alternative Solution 4 & 2319 & 208 \\
Alternative Solution 5 & 2061 & 234 \\
Alternative Solution 6 & 1855 & 260 \\
Alternative Solution 7 & 1686 & 286 \\
Alternative Solution 8 & 1546 & 312 \\
\hline
\end{tabular}

\subsection{Alternative scenario selection with TOPSIS method}

Because of the solution of the mathematical model, The TOPSIS method is used to select the most suitable alternative solution according to the number of regular trips. Owing to the method, the best among alternative solutions is chosen. An expert team consisting of TCDD representatives have determined the criteria for the selection of alternative scenarios. These criteria and definitions are as follows:

- The Annual Number of trips: It is the total number of train trips made in a year.

- Ramp cost: It is the cost of using ramps for shipping.

- Outgoing freight amount: It is the amount of freight sent from The Kars logistics center for each trip.

- Container Holdings: It is the status of holding containers in the stockpile according to the number of trips and the outgoing freight. This criterion is scored between 1-5 based on the ratio of the number of days with no trips to the amount of outgoing freight.

The expert team have accepted these criteria as equally weighted. The decision matrix of eight alternative solutions is given in Table 5 .

The TOPSIS method solution process consists of 6 steps [25, 26]:

1) Creating the Decision Matrix $\left(\mathrm{A}_{\mathrm{ij}}\right)$ : There are alternatives in the rows of the decision matrix and the criteria that are decisive in decision making in the columns. The initial decision matrix for the problem is Equation 13: 


$$
A_{i j}=\left[\begin{array}{cccc}
a_{11} & a_{12} & \ldots & a_{1 n} \\
a_{21} & a_{22} & \ldots & a_{2 n} \\
\cdot & & & \cdot \\
\cdot & & & \cdot \\
\cdot & & & \cdot \\
a_{m 1} & a_{m 2} & \ldots & a_{m n}
\end{array}\right]
$$

Table 5. Decision matrix

\begin{tabular}{lcccc}
\hline & Trips & Ramp Cost (TRY) & $\begin{array}{c}\text { Outgoing Freight } \\
\text { Amount }\end{array}$ & Container Holdings \\
\hline Alternative Solution 1 & 130 & 491.79 & 542 & 2 \\
Alternative Solution 2 & 156 & 409.76 & 451 & 1 \\
Alternative Solution 3 & 182 & 351.26 & 387 & 1 \\
Alternative Solution 4 & 208 & 307.32 & 339 & 1 \\
Alternative Solution 5 & 234 & 273.13 & 301 & 2 \\
Alternative Solution 6 & 260 & 245.83 & 271 & 3 \\
Alternative Solution 7 & 286 & 223.47 & 246 & 4 \\
Alternative Solution 8 & 312 & 204.88 & 226 & 5 \\
\hline
\end{tabular}

2) Creating the Standard Decision Matrix $\left(\mathrm{R}_{\mathrm{ij}}\right)$ : The Standard Decision Matrix is created by normalizing the decision matrix (Equation 14-15).

$$
\begin{gathered}
r_{i j}=\frac{a_{i j}}{\sqrt{\sum_{k=1}^{m} a_{k j}^{2}}} \\
R_{i j}=\left[\begin{array}{cccc}
r_{11} & r_{12} & \ldots & r_{1 n} \\
r_{21} & r_{22} & \ldots & r_{2 n} \\
\cdot & & & \cdot \\
\cdot & & & \cdot \\
\cdot & & & \cdot \\
r_{m 1} & r_{m 2} & \ldots & r_{m n}
\end{array}\right]
\end{gathered}
$$

3) Creating the Weighted Standard Decision Matrix $\left(V_{\mathrm{ij}}\right)$ : Each element of the standard decision matrix is multiplied by the weight value of the criterion $\left(\mathrm{w}_{\mathrm{i}}\right)$ for that column and a weighted standard decision matrix is created. In the problem, criteria are considered equally weighted (Equation 16). 


$$
V_{i j}=\left[\begin{array}{cccc}
w_{1} r_{11} & w_{2} r_{12} & \ldots & w_{n} r_{1 n} \\
w_{1} r_{21} & w_{2} r_{22} & \ldots & w_{n} r_{2 n} \\
\cdot & & & \cdot \\
\cdot & & & \cdot \\
\cdot & & & \cdot \\
w_{1} r_{m 1} & w_{2} r_{m 2} & \ldots & w_{n} r_{m n}
\end{array}\right]
$$

4) Creating Positive Ideal $\left(\mathrm{V}^{+}\right)$and Negative Ideal Solutions ( $\left.\mathrm{V}^{-}\right)$: TOPSIS essentially determines that the chosen alternatives should have the closest and furthest distance (Euclidean measurement) and therefore calculating the relative proximity of an alternative to the optimal solution will produce a positive ideal solution and a negative ideal solution (Equation 17-18).

$$
\begin{aligned}
V^{+} & =\left\{\left(\max _{i} v_{i j} \mid j \in J\right),\left(\min _{i} v_{i j} \mid j \in J^{\prime}\right\}\right. \\
V^{-} & =\left\{\left(\min _{i} v_{i j} \mid j \in J\right),\left(\max _{i} v_{i j} \mid j \in J^{\prime}\right\}\right.
\end{aligned}
$$

5) Calculation of Discrimination Measures: In the TOPSIS method, dimensional euclidean measurement is used to find the deviations from positive ideal $\left(\mathrm{S}_{\mathrm{i}}^{+}\right)$and negative ideal $\left(\mathrm{S}_{\mathrm{i}}^{-}\right)$ solution set of the criterion value for each alternative (Equation 19-20).

$$
\begin{gathered}
S_{i}^{+}=\sqrt{\sum_{j=1}^{n}\left(v_{i j}-v_{j}^{+}\right)^{2}} \\
S_{i}^{-}=\sqrt{\sum_{j=1}^{n}\left(v_{i j}-v_{j}^{-}\right)^{2}}
\end{gathered}
$$

6) Calculation of Relative Proximity to Ideal Solution $\left(\mathrm{C}_{\mathrm{i}}^{*}\right)$ : The relative proximity value $\left(\mathrm{C}_{\mathrm{i}}^{*}\right)$ of each alternative to the ideal solution is calculated using positive ideal and negative ideal separation measures. The relative proximity to the ideal solution is the ratio of the negative ideal measure of discrimination within the total measure of discrimination. Here, the value of $\mathrm{C}_{\mathrm{i}}{ }^{*}$ is in the range of $0 \leq \mathrm{C}_{\mathrm{i}}{ }^{*} \leq 1$, and $\mathrm{C}_{\mathrm{i}}{ }^{*}=1$ means the absolute proximity of the alternative to the positive ideal solution, and $\mathrm{C}_{\mathrm{i}}{ }^{*}=0$ to the negative ideal solution of the relevant alternative. The positive, negative, and ideal solution values of alternative solutions of the problem are given in Table 6 (Equation 21).

$$
C_{i}^{*}=\frac{S_{i}^{-}}{S_{i}^{-}+S_{i}^{+}}
$$

According to the results obtained from the TOPSIS method, the optimal solution is the fourth alternative solution based on the number of trips, outgoing freight amount, ramp cost, and the container holding criteria. In other words, if the Kars logistics center is used with full capacity, considering the estimated annual outbound freight, the amount of freight received per transport is 2319 tons and the number of train trips per year is 208 , which will create the ideal situation in terms of capacity and cost. 
Table 6. Positive, negative, and ideal distance values

\begin{tabular}{cccc}
\hline & $\mathrm{S}_{\mathrm{i}}^{+}$ & $\mathrm{S}_{\mathrm{i}}^{-}$ & $\mathrm{C}_{\mathrm{i}}^{*}$ \\
\hline Alternative Solution 1 & 0.118625586 & 0.08680616 & 0.42255475 \\
Alternative Solution 2 & 0.087905248 & 0.118510019 & 0.57413398 \\
Alternative Solution 3 & 0.080449878 & 0.114654584 & 0.58765742 \\
Alternative Solution 4 & 0.075575331 & 0.115539111 & 0.60455458 \\
Alternative Solution 5 & 0.097525553 & 0.071296634 & 0.42231792 \\
Alternative Solution 6 & 0.112726931 & 0.073899513 & 0.39597557 \\
Alternative Solution 7 & 0.122184813 & 0.085694915 & 0.41223315 \\
Alternative Solution 8 & 0.129583171 & 0.099320364 & 0.43389615 \\
\hline
\end{tabular}

\section{Conclusion}

In this study, a logistics model that maximizes capacity utilization and presents the most ideal freight transportation is proposed for Kars logistics center. In the first step of this model, the estimated incoming and outgoing freight for the next years was determined by the exponential adjustment method. In the second phase, the total freight transport amount (annual) that maximized the capacity of the Kars logistics center was determined with the help of a mathematical model that took these freight amounts into account. In the third phase, the most appropriate alternative annual number of trips and freight amounts per transport, which constituted these total freight transport amounts, was decided by the TOPSIS method according to the number of trips, outgoing freight amount, ramp cost, and the container holding criteria. The proposed model was intended to contribute to the literature and intended to provide an application area for the capacity analysis of a logistics center. As a result of the analysis made for the Kars logistics center, it was concluded that its capacity was planned more than the current freight input freight output and financial investment was made more than necessary. This has led to an increase in extra cost and use of idle space. According to the results obtained from the solution of the proposed model, if the Kars logistics center is used at full capacity, the amount of freight per transport is 2319 tons and the number of trains per year is 208 , which will create the ideal situation in terms of capacity and cost. Among the various criteria in the evaluation of logistics centers, the size of the area, and the efficient use of the area are the most important. As a result of the analysis, it is concluded that the investments made in the Kars logistics center can fail. Especially developing countries need to make a preliminary study to both make the right investment and reach the quality standards. Therefore, the model proposed in this study is an example of capacity analysis. This study hopes to contribute to the project makers who intend to build efficient and effective logistics centers.

In future studies, the proposed model can be applied for different logistics centers. In addition, criteria can be weighted by using methods such as AHP in the selection of alternative scenarios.

\section{References}

[1] N. Terzi, O. Bolukbas, "Logistics sector in Turkey and logistics villages," PressAcademia Procedia, vol. 2, no. 1, pp. 206-228, 2016, doi: 10.17261/Pressacademia.2016118643

[2] S.E. Demir, "Lojistik Bir Merkez Olarak Gemlik," Master's Thesis, Fen Bilimleri Enstitüsü, Bahçeșehir Üniversitesi. Ankara, 2016 
[3] İ. Önden, F. Eldemir, M. Canci, "Logıstıcs Center Concept And Locatıon Decısıon Criterıa. Sigma," Journal of Engineering \& Natural Sciences, ” vol. 33, no. 3, pp. 325-340, 2015

[4] M. Abril, F. Barber, L. Ingolotti, M.A. Salido, P. Tormos, A. Lova, "An assessment of railway capacity," Transportation Research Part E: Logistics and Transportation Review, vol. 44, no. 5, pp.774-806, 2008, doi: 10.1016/j.tre.2007.04.001

[5] K. Yıldı, M.A. Yerlikaya, B.N. Keskin, "Evaluation of the Effect of Transport Networks on the Kemalpaşa Logistics Center in Logistics Site Selection," Politeknik Dergisi, Article in press, 2021, doi: 10.2339/politeknik.731997

[6] B. Li, D. Krushinsky, H.A. Reijers, T. Van Woensel, "The share-a-ride problem: People and parcels sharing taxis," European Journal of Operational Research, vol. 238, no. 1, pp. 31-40, 2014, doi: 10.1016/j.ejor.2014.03.003

[7] E. Fatnassi, J. Chaouachi, W. Klibi, "Planning and operating a shared goods and passengers on-demand rapid transit system for sustainable city logistics," Transportation Research Part B: Methodological. vol. 81, pp. 440-460, 2015, doi: 10.1016/j.trb.2015.07.016

[8] J. Kikuta, T. Ito, I. Tomiyama, S. Yamamoto, T. Yamada, "New subway-integrated city logistics system," Procedia-Social and Behavioral Sciences, vol.39, pp. 476-489, 2012, doi: 10.1016/j.sbspro.2012.03.123

[9] A. Motraghi, M.V. Marinov, "Analysis of urban freight by rail using event based simulation," Simulation Modelling Practice and Theory, vol. 25, pp. 73-89, 2012, doi: 10.1016/j.simpat.2012.02.009

[10] M.A. Figliozzi, "Analysis of the efficiency of urban commercial vehicle tours: Data collection, methodology, and policy implications," Transportation Research Part B: Methodological, vol. 41, no. 9, pp. 1014-1032, 2007, doi: 10.1016/j.trb.2007.04.006

[11] A. Benjelloun, T.G. Crainic, "Trends, challenges, and perspectives in city logistics," Transportation and land use interaction, proceedings TRANSLU, vol. 8, pp. 269-284, 2009

[12] S. Behrends, "The significance of the urban context for the sustainability performance of intermodal road-rail transport," Procedia-Social and Behavioral Sciences, vol. 54, pp. 375-386, 2012

[13]R. Burdett, E. Kozan, "Techniques for absolute capacity determination in railways," Transportation Research Part B: Methodological, vol. 40, no. 86, pp. 16-632, 2006, doi: 10.1016/j.trb.2005.09.004

[14] Y. Sun, Y. Lu, C. Zhang, "Fuzzy Linear Programming Models for a Green Logistics Center Location and Allocation Problem under Mixed Uncertainties Based on Different Carbon Dioxide Emission Reduction Methods," Sustainability, vol. 11, no. 22, pp. 6448, 2019, doi: 10.3390/su11226448

[15]L. Xue, X. Huang, Y. Wu, X. Yan, Y. Zheng, "Grade Setting of a Timber Logistics Center Based on a Complex Network: A Case Study of 47 Timber Trading Markets in China," Information vol. 11, no. 2, pp. 107, 2020, doi: 10.3390/info11020107

[16]L. Peceny, P. Mesko, R. Kampf, J. Gasparik, "Optimisation in Transport and Logistic Processes," Transportation Research Procedia, vol. 44, pp. 15-22, 2020, doi: 10.1016/j.trpro.2020.02.003

[17]B. Abramovic, V. Zitricky, P. Mesko, "Draft methodology to specify the railway sections capacity," LOGI-Scientific Journal on Transport and Logistics, vol. 8, no. 1, pp. 1-10, 2017, doi: 10.1515/logi2017-0001

[18] B. Bevrani, R.L. Burdett, A. Bhaskar, P.K. Yarlagadda, "A capacity assessment approach for multimodal transportation systems.” European Journal of Operational Research, vol. 263, no.3, pp. 864878, 2017, doi: 10.1016/j.ejor.2017.05.007

[19] N. Bešinović, R.M. Goverde, "Capacity assessment in railway networks," In Handbook of Optimization in the Railway Industry, pp. 25-45, Cham: Springer, 2018

[20] B. Luteberget, K. Claessen, " Design-time railway capacity verification using SAT modulo discrete event simulation," In 2018 Formal Methods in Computer Aided Design (FMCAD), IEEE, 2018

[21]B. Elevli, "Logistics freight center locations decision by using Fuzzy-PROMETHEE," Transport, vol. 29, no.4, pp. 412-418, 2014, doi: 10.3846/16484142.2014.983966

[22]A. Üzümcü, S. Akdeniz, "Yeni ipek yolu: TRACECA ve Bakü-Tiflis-Kars demiryolu projesi," Avrasya Etüdleri, vol. 45, no. 1, pp. 11-39, 2014

[23] Ç. Polat, "Yapay Sinir Ağları Ve Üstel Düzeltme Yöntemleri İle Talep Tahmini Ve Bir Uygulama," Master's Thesis, Dokuz Eylül Üniversitesi, İzmir, 2016

[24] H.Z. Nazir, M. Abid, N. Akhtar, M. Riaz, S. Qamar, “ An Efficient Mixed-Memory-Type Control Chart for Normal and Non-Normal Processes," Scientia Iranica, Article In Press, 2019, doi: 10.24200/SCI.2019.51437.2177 
[25] M. Monjezi, H. Dehghani, T.N. Singh, A.R. Sayadi, A. Gholinejad, "Application of TOPSIS method for selecting the most appropriate blast design," Arabian Journal of Geosciences. vol. 5, no. 1, pp. 95101, 2012, doi: 10.1007/s12517-010-0133-2

[26]F. Sarı, "Forest fire susceptibility mapping via multi-criteria decision analysis techniques for Mugla, Turkey: A comparative analysis of VIKOR and TOPSIS," Forest Ecology and Management. Article vol. 480, pp. 118644, 2021, doi: 10.1016/j.foreco.2020.118644

\section{Resume}

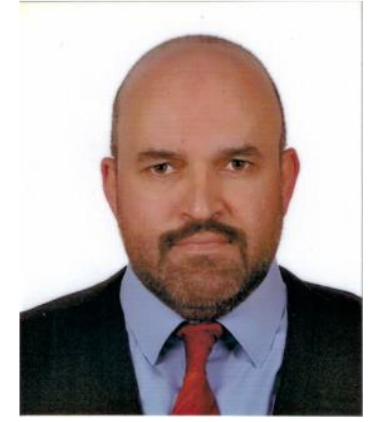

\section{Kürşat YILDIZ}

He was born in 1978. He studied and is experienced in different research areas of civil engineering, logistics, statistical methods, decision tools and supply chain management and performance systems. He is an academician in the civil engineering department of Gazi University and conducting different researches and thesis in supply chain management, transportation, traffic management and other high trending topics dealing with the industrial problems.

E-mail: kursaty@gazi.edu.tr

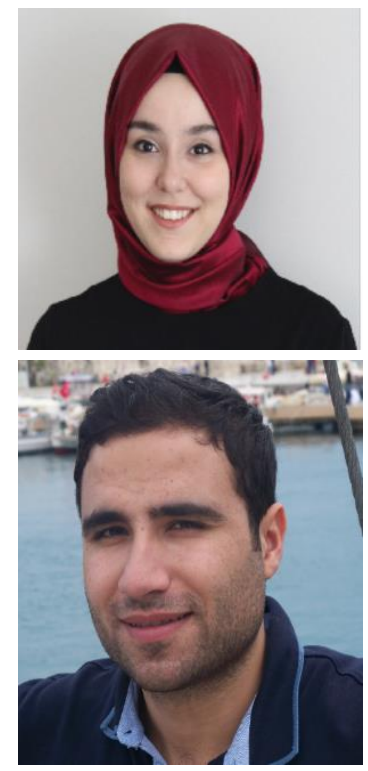

\section{Zehra EFE}

She was born in 1995. She completed his undergraduate education at Çankaya University and her graduate education at Gazi University. She works in a private firm. Her research interests are railroad, land use planning and sociological analysis.

E-mail: fzehraefe@gmail.com

\section{Mehmet Akif YERLIKAYA}

He was born in 1987. He completed his undergraduate education at Kocaeli University in 2009, his master's degree from Gazi University in 2014 and his doctorate education from Gazi University in 2019. The field of study is order picking systems, multi-criteria decision making and logistics management.

E-mail: mayerlikaya@beu.edu.tr

\section{Ethics Statement:}

Authors confirm that the article is original, there is no plagiarism issue.

All authors contributed equally. 